\title{
Botulinum toxin type A in chronic neuropathic pain in refractory leprosy
}

\author{
Toxina Botulínica Tipo A em Dor Neuropática Crônica em Hanseníase \\ Emanuel de Jesus Soares de SOUSA', Gustavo Celeira de SOUSA', Vitor Ferreira BAIA', Danusa Neves \\ SOMENSI', Marília Brasil XAVIER ${ }^{1,2}$
}

\begin{abstract}
Neuropathic pain is a chronic syndrome that is difficult to treat and often affects patients with leprosy. Recommended treatment includes the the use of analgesic drugs, codeine, tricyclic antidepressants, neuroleptics, anticonvulsants and thalidomide, but without consensus on uniform dose and fully satisfactory results. Objective: To analyze botulinum toxin type A (BoNT-A) effectiveness in treatment of chronic neuropathic pain in refractory leprous patients, as well as evaluate and compare the quality of life of patients before and after using the medication. Methods: We used a specific protocol including clinical, demographic, DN4 protocol, analogue scale (VAS), sensory evaluation and evaluation of the WHOQOL-BREF. Therapeutic intervention was performed with BOTOX® BTX-A 100U administered subcutaneously. Fifteen patients were evaluated on days 0,10 and 60. Results: Patients on VAS showed pain between 5 and 10, in one case there was complete pain relief in 60 days, while others showed improvement in the first week with the return of symptoms with less intensity after this period. WHOQOL-BREF's domains Quality of Life and Physical to have a significant increase in QOL. Conclusion: BoNT-A proved to be a good therapeutic option in relieving pain with improved quality of life for these patients.
\end{abstract}

Keywords: Leprosy; botulinum toxins.

\section{RESUMO}

A dor neuropática é uma síndrome crônica que é difícil de tratar e freqüentemente afeta pacientes com hanseníase. 0 tratamento recomendado inclui o uso de drogas analgésicas, codeína, antidepressivos tricíclicos, neurolépticos, anticonvulsivantes e talidomida, mas sem consenso sobre dose uniforme e resultados plenamente satisfatórios. Objetivo: Busca-se analisar a efetividade da toxina botulínica tipo A no tratamento da dor neuropática crônica hansênica refratária. Método: Estudo de intervenção do tipo ensaio clínico em portadores de dor neuropática crônica hansênica. Foram coletados dados epidemiológicos, protocolo DN4, escala analógica da dor (EVA), avaliação sensitiva, motora a avaliação do WHOQOL-Bref. Realizado intervenção terapêutica com toxina botulínica tipo A $100 \mathrm{U}$. Os pacientes foram avaliados nos dias de 0,10 e 60. A dor neuropática foi mais frequente no sexo masculino, na faixa etária de 40 à 49 anos. Resultados: Da forma Dimorfa, multibacilar com baciloscopia positiva e incapacidades presentes. Os escores EVA variam entre 5 e 10, todos os pacientes apresentaram alterações sensoriais. O WHOQOL-Bref apresentou melhora após o tratamento com TxBA. A TxBA foi bem tolerada o único efeito adverso notável foi dor leve. E com apenas uma única aplicação de TxBA promoveu efeitos analgésicos a longo prazo em pacientes com dor associada à alodinia, sugerindo que a analgesia observada pode ser causada por um efeito periférico da TxBA em terminações nociceptivas. Conclusão: 0 estudo sugere que a TxBA é uma boa opção para os casos de dor neuropática crônica hansênica, no entanto, novos estudos são necessários para confirmar estes resultados.

Palavras-chave: Hanseníase; toxinas botulínicas.

Leprosy is a chronic granulomatous disease caused by Mycobacterium leprae, a bacterium with predilection for skin cells and peripheral nerve tissue. Thus, it causes skin and neurological manifestations as well as inflammatory reactions with consequent sensory and motor changes ${ }^{1}$.
M. leprae has tropism for peripheral nervous system, infecting Schwann cells and occasionally endothelium. Microscopic lesions' alterations include degeneration of Schwann cells, loss of myelin, axonal retraction, periaxonal fibrosis and a variable amount of immunopathological

\footnotetext{
'Universidade do Estado do Pará, Centro de Ciências Biológicas e da Saúde, Belém PA, Brasil;

2 Universidade Federal do Pará, Centro de Medicina Tropical, Laboratório de Pesquisas em Dermatologia Tropical e Doenças Endêmicas, Belém PA, Brasil.

Emanuel de Jesus Soares de Sousa (iD) https://orcid.org/0000-0002-9563-4262

Correspondence: Emanuel de Jesus Soares de Sousa; Núcleo de Medicina Tropical da Universidade Federal do Pará, Laboratório de Pesquisas em Dermatologia Tropical e Doenças Endêmicas; Av. Gen. Deodoro, 92 - Umarizal; 66055-240 Belém PA, Brasil; E-mail: ejsunineuro@gmail.com

Conflict of interest: There is no conflict of interest to declare.

Support: National Council for Scientific and Technological Development - CNPq.

Received 18 November 2018; Received in final form 12 March 2019; Accepted 20 March 2019.
} 
responses that result in progressive impairment of nerve fibers ${ }^{2,3,4,5}$.

There are two most common causes of pain in leprosy patients: leprosy reactions (LR), which involve acute, inflammatory episodes of neuritis; and chronic pain resulting from neuropathic damage. LR neuritis treatment involves anti-inflammatory drugs, like prednisone; whereas neuropathic pain (NP) may be managed with prednisone or dexametasone for type I reactions and thalidomide for type II reactions ${ }^{6}$. Tricyclic antidepressants (particularly amitriptyline), serotonin-norepinephrine reuptake inhibitors (particularly duloxetine), pregabalin, gabapentin, tramadol, strong opioids and botulinum toxin A (BoNT-A) are treatment options for $\mathrm{NP}^{7}$.

The presence of neural damage sequelae is remarkable amongst leprosy patients. Many studies have shown that NP is one leprosy's major sequelae, found in over $70 \%$ of patients. Other prevalence factor of NP is the presence of LR, mainly type II reactions. In addition, even the full therapy was unable to treat NP, which affects patients' quality of life and mental health moderately to intensely ${ }^{8,9,10}$.

Overt neuritis is statistically associated with evolution in the leprosy degree of disability ${ }^{11}$. It is stated as pain presence, spontaneous or by palpation, of a peripheral nerve trunk, with or without impaired function, possibly leading to nerve damage, alterations in free nerve endings and nerve trunks, that may cause loss of sensation, paresis, plegias and muscular atrophies, which if not diagnosed and properly treated, may progress to permanent physical disabilities ${ }^{12}$.

In Brazil, leprosy is the most common underlying cause for peripheral neuropathy treatment, and despite being an age-old disease, it still challenges humanity. Moreover, a significant portion of patients, even after discharge from specific medication, suffers from the sequelae of nerve damage caused by the disease ${ }^{13}$.

Brazil's leprosy epidemiology bulletins (2018) indicate that there is still high prevalence of such disease in the country, which is therefore recognized as an endemic zone, with medium detection rate of 14.97 new cases per 100,000 inhabitants ${ }^{14}$. Thus, the association of early diagnosis and appropriate treatment has vital significance for the affected population's quality of life improvement ${ }^{15}$.

These observations denote the need for new studies, including commonly used drugs for neuropathic pain treatment; also, there is no description of botulinum toxin type A for chronic neuropathic pain control in leprosy. Thus, the aim of this study was to analyze the effectiveness of botulinum toxin type A (BoNT-A) in chronic neuropathic pain in refractory leprous patient treatment, as well as to evaluate and compare the quality of life of patients before and after using such medication.

\section{METHODS}

This was a self-control open-label study of therapeutic intervention in patients with chronic neuropathic pain after leprosy refractory treatment ${ }^{6}$. Botulinum toxin (neuromuscular junction blocker) was used for treatment. The study groups were assessed and monitored for a period of eight weeks (two months). Patients were evaluated on days 0,10 and 60 .

Patients invited to participate in the study were selected from the referral center for the care of leprosy in the city of Belém, Pará, Brazil, represented by outpatient clinics of the Tropical Medicine Center (TMC) and the Health Center School - Marco (CSEM). Overall, 163 patients with leprosy and pain were assessed, of whom, only 41 met the minimum criteria to be included in the study (age above 15 years and chronic neuropathic pain). However, 20 of these patients showed other conditions such as diabetes, HIV, and chronic alcoholism and were therefore excluded. The remaining sample comprised 21 patients with chronic neuropathic pain leprosy, of which only 15 agreed to participate.

Until study end, the 15 patients treated or not with multidrug therapy (MDT) presented alteration of dermatologic/neurologic examination, like sensory or motor deficit. The NP was characterized by Douler Neuropathique en 4 Questions (DN4) above 4 in 10, visual analog scale (VAS) above 5 and were submitted to treatment for neuropathic pain with drugs proposed by the Brazilian Ministry of Health ${ }^{6}$ with no improvement in the clinical condition. Quality of Life was assessed and measured through World Health Organization Quality of Life Brief Questionaire (WHOQOL-Bref) at the beginning and end of study.

Also, Chen et al. ${ }^{16}$ criteria were included in this study, which establishes chronic neuropathic pain leprosy as a painful condition of at least two years after treatment with MDT or after three months with continuous or uninterrupted pain, associated or not with leprosy reaction, with no evidence to suggest other causes, such as infected ulcers.

Botox ${ }^{\circ}$ BTX-A $100 \mathrm{U}$ administration followed Patil et. al. ${ }^{17}$ recommendations (Dilution in $2 \mathrm{~mL}$ of $0.9 \%$ saline solution, where each 0.1 cc match $5 \mathrm{U}$ of BoNT-A). Application followed dermatomes or affected nerve endings, determined by clinical and neurophysiological examination and marked with a color pen ${ }^{17}$ (Figure 1).

The study received approval of the insitutions' Ethics Committee.

\section{RESULTS}

All 15 participants met the inclusion criteria and thus were submitted to treatment with BoNT-A. 

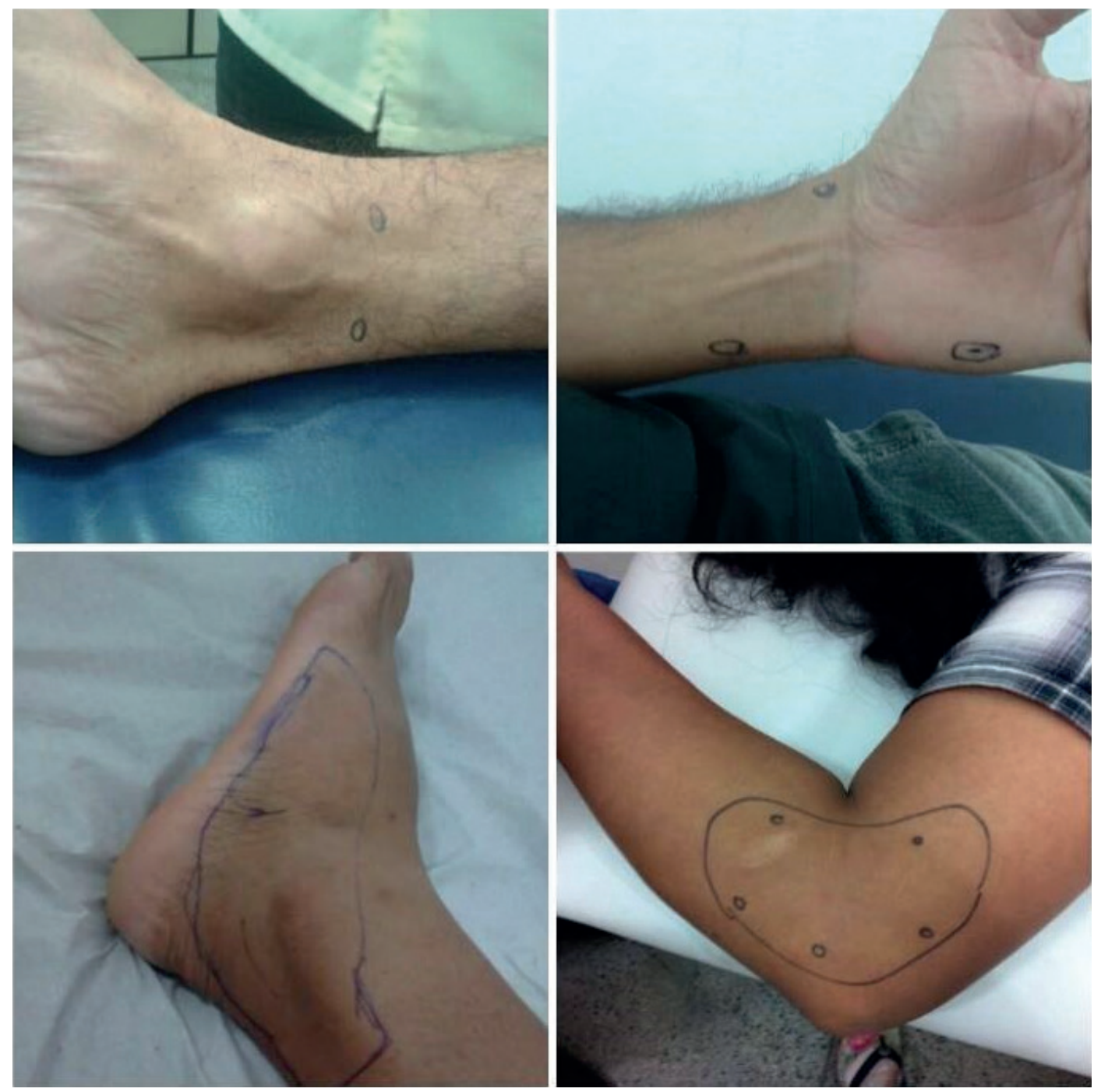

Figure 1. Application points of botulinum toxin.

Patients had longstanding chronic pain which lasted 1 to 20 years (mean time $=4.4$ years), with no significant difference in pain time $(p=0.4562)$. About pain site, there was significant incidence of commitment of upper and lower limbs concomitantly (46.7\%, $\mathrm{p}=0.0457)$ (Table).

We observed a significant increase $(p=0.0010)$ of strength after application of the toxin. This increase occurred from the tenth day after the use of medication ( $p=0.0361)$, reaching its peak on the sixtieth day of evaluation (Figure 2).

Pain intensity evaluation (VAS) showed significant reduction $(\mathrm{p}=0.0057)$ from days 10 to 60 . The therapy reduced pain levels quickly in the first week after BoNT-A application and stabilized on the remaining days until study end (Figure 3).

We found an increase in all domains of the QoL scale, with the Quality of Life $(\mathrm{p}=0.0147$ *) and Physical $(\mathrm{p}=0.0052)$ domains significantly different between these periods, since these domains reported better quality of life after intervention. The comparison between domains showed significant difference only before treatment $(\mathrm{p}=0.0134)$ (Figure 4).
In relation to adverse effects, five patients complained of headache, tingling, nausea, fever, drowsiness, left foot edema and pain in the right lower limb on the first week after application. However, such complaints were not known as adverse effects of medication.

\section{DISCUSSION}

Pimentel ${ }^{12}$ evaluated 103 patients with multibacillary leprosy, highlighting peripheral nerve involvement at diagnosis, disability degree before treatment and occurrence of neuritis episodes during and after multidrug therapy, which led to discovery that the ulnar nerve is the main damaged nerve. Similar results were found in this study, with 12 cases (80\%) of ulnar and tibial, 10 cases (66.67\%) of radial and nine cases (60\%) of fibular nerve damage 2 .

Chen et al. ${ }^{16}$ described neuropathic pain prevalence of 126 patients within a 275-leprosy patient's sample (45.8\%), exposing this disorder severity. In addition, 109 patients (86.5\%) 
Table. Sociodemographic and clinical characteristics of patients with chronic neuropathic pain.

\begin{tabular}{|c|c|c|c|}
\hline Variables & Frequency & $\%$ & $\mathrm{p} X^{2}$ \\
\hline \multicolumn{4}{|l|}{ Sex } \\
\hline Female & 6 & 40 & \multirow{2}{*}{0.0486} \\
\hline Male* & 9 & 60 & \\
\hline \multicolumn{4}{|c|}{ Age group (years) } \\
\hline$<30$ & 3 & 3.8 & \multirow{4}{*}{0.0402} \\
\hline 30 to 39 & 4 & 5.0 & \\
\hline 40 to $49 *$ & 6 & 7.5 & \\
\hline$\geq 50$ & 2 & 2.5 & \\
\hline Mean-female & 36.2 (SD 6.7) & & \\
\hline Mean-male & 45.9 (SD 14.3) & & \\
\hline Mean-general & 42 (SD 13) & & \\
\hline \multicolumn{4}{|c|}{ Madrid classification } \\
\hline Dimorphic* & 11 & 73.3 & \multirow{4}{*}{$<0.0001$} \\
\hline Virchow & 2 & 13.3 & \\
\hline Tuberculoid & 1 & 6.7 & \\
\hline Pure neural & 1 & 6.7 & \\
\hline \multicolumn{4}{|c|}{ WHO classification } \\
\hline$M B^{*}$ & 13 & 86.7 & \multirow{2}{*}{$<0.0001$} \\
\hline PB & 2 & 13.3 & \\
\hline \multicolumn{4}{|l|}{ Reactions } \\
\hline Type I & 8 & 53.5 & \multirow{3}{*}{0.3147} \\
\hline Type II & 2 & 13.3 & \\
\hline Absent & 5 & 33.3 & \\
\hline \multicolumn{4}{|c|}{ Bacilloscopy $(n=14)$} \\
\hline Positive* & 10 & 66.7 & \multirow{2}{*}{0.0291} \\
\hline Negative & 4 & 26.7 & \\
\hline \multicolumn{4}{|l|}{ Incapacity } \\
\hline Absent & 2 & 13.3 & \multirow{2}{*}{0.0098} \\
\hline Present & 13 & 86.7 & \\
\hline
\end{tabular}

referred that pain had impact over Quality of Life, being that 13 (10.3\%) patients referred mild, 45 (35.7\%) referred moderate and $51(40.5 \%)$ referred severe interference of pain in Quality of Life. Actual literature also confirms sociodemographic aspects of the leprous population, finding similar results to our study ${ }^{16}$.

In all cases, there was a reduction of pain since five days after application. In one of the reported cases, there was significant reduction of pain that lasted for eight weeks. Chen and Chuang ${ }^{18}$ made serial applications with three-month intervals and thus maintained the pain score near zero in a group of patients with post-herpetic neuralgia. Our main results showed that a single subcutaneous application of BoNT-A induces a long-term analgesic effect on neuropathic pain. The effects found had quantified measures, particularly the evaluation of VAS, as a way of pain assessment. We observed reduction in the intensity of allodynia in
Strength Degree

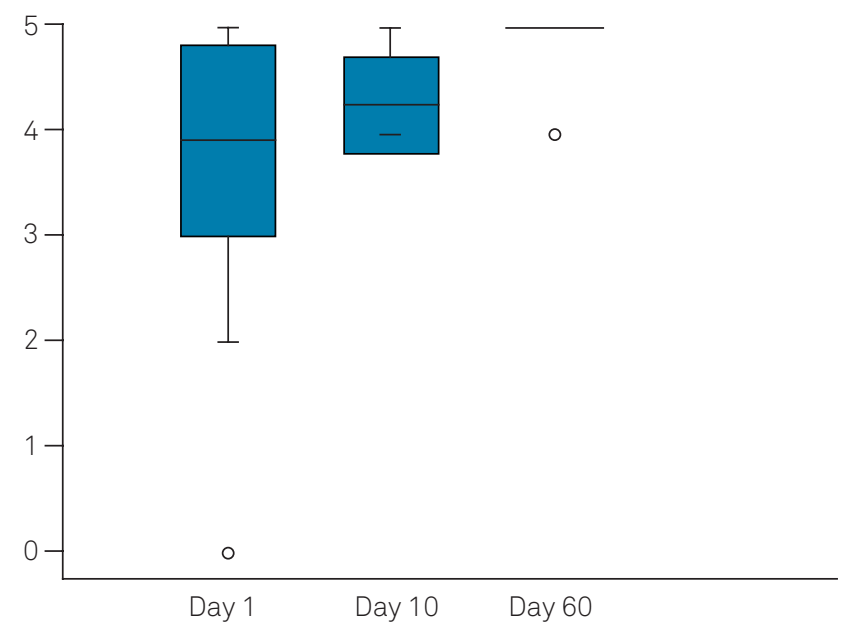

Figure 2. Oxford Strength Scale degree.

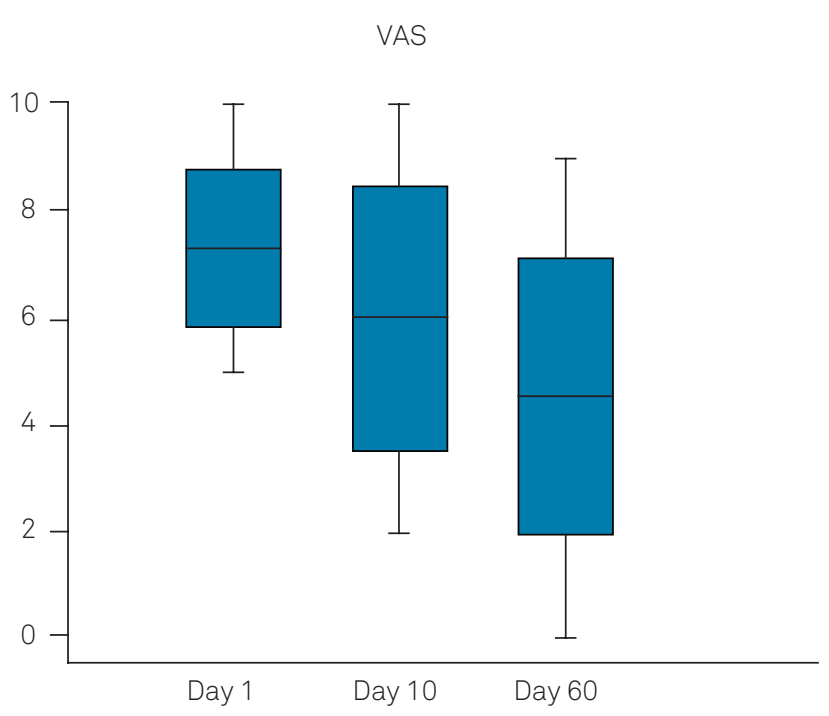

Figure 3. Visual Analogue Scale for pain

Whoqol-bref

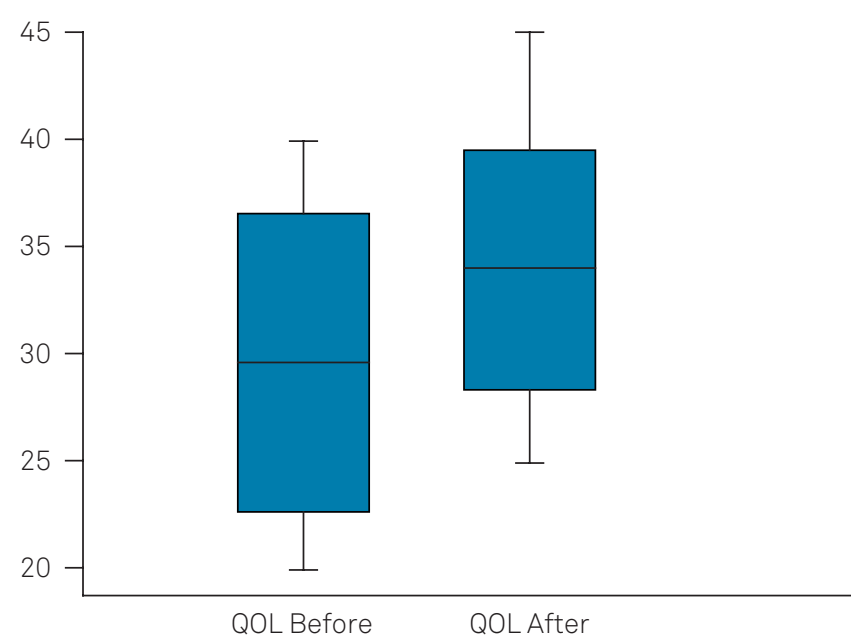

Figure 4. World Health Organization Quality of Life Brief Questionaire (WHOQOL -Bref). 
the affected nerve territory from the first week lasting until the eighth ${ }^{18}$.

Neuropathic symptoms and some quality of life questions improved in our patients. These characteristics indicate that BoNT-A has selective effects on neuropathic pain likely indicating new mechanisms for analgesia. Similar results can be seen in Park's studies (2017) regarding whether the occurrence of pain is spontaneous or not, its intensity, its perception mechanism, neuropathic symptoms and quality of life of these patients at weeks 0, 4, 12 and 24 after application BoNT- $\mathrm{A}^{19}$.

Xiao et al. ${ }^{20}$ reported sixty cases of post-herpetic neuralgia treated with BoNT-A (Botox ${ }^{\circ}$ ) in dilution $5 \mathrm{u} / \mathrm{mL}$, and applied $5 \mathrm{IU}$ per point, for a total of $100 \mathrm{IU}$. The severity of pain was assessed by VAS, with a significant reduction from the seventh day and maintained until three months. In relapse, pain was considered less severe and tolerable by patients ${ }^{20}$.

Other studies corroborate the usefulness of botulinum toxin A in peripheral neuropathic pain treatment ${ }^{21,22}$. Therefore, the specific study in the treatment of patients with leprosy is of great importance.
In conclusion, botulinum toxin displayed the action described in diseases that occur with excessive muscle contraction, as facial spasm, spasticity, in addition to its indication in some pain syndromes, like migraine and painful neuropathies.

The study proposed the therapeutic use of botulinum toxin in leprosy patients who evolved with neuropathic pain. The toxin had good tolerance, as the only notable side effect was transient mild to moderate pain during injections in many patients, especially when applied to extremities and affected nerve territories.

With only a single subcutaneous injection of BoNT-A, direct analgesic effects over the long term were promoted in patients with chronic neuropathic pain leprosy associated with allodynia, suggesting that the analgesia observed may be caused by a local peripheral effect of BoNT-A on nociceptive nerve endings, although subsequent central effects are possible. The study suggests that BoNT-A is a good option for cases of chronic neuropathic pain leprosy; however, further studies are needed to confirm these results.

\section{References}

1. Costa MD, Terra FS, Costa RD, Lyon S, Costa AM, Antunes CM. Assessment of quality of life of patients with leprosy reactional states treated in a dermatology reference center. An Bras Dermatol. 2012 Jan-Feb;87(1):26-35. https://doi.org/10.1590/S0365-05962012000100003

2. Giesel LM, Pitta IJ, Silveira RC, Andrade LR, Vital RT, Nery JA, et al. Clinical and neurophysiological features of leprosy patients with neuropathic pain. Am J Trop Med Hyg. 2018 Jun;98(6):1609-13. https://doi.org/10.4269/ajtmh.17-0817

3. Michellin LB, Barreto JA, Marciano LHSC, Lara FA, Nogueira MES, Souza VNBet al. Leprosy patients: neurotrophic factors and axonal markers in skin lesions. Arq. Neuro-Psiquiatr. 2012 Apr;70(4):281-6. https://doi.org/10.1590/S0004-282X2012000400012

4. Cohen SP, Mao J. Neuropathic pain: mechanisms and their clinical implications. BMJ. 2014 Feb;348(348):f7656. https://doi.org/10.1136/bmj.f7656

5. Alves ED, Ferreira TL, Ferreira IN, orgs. Hanseníase : avanços e desafios. Brasília, DF: NESPROM; 2014

6. Ministério da Saúde (BR). Secretaria de Vigilância das Doenças Transmissiveis. Guia prático sobre a hanseníase. Brasília, DF: Ministério da Saúde. 2017 [cited 2019 Jan 14]. Available from: http://bvsms.saude.gov.br/bvs/publicacoes/guia_pratico_ hanseniase.pdf

7. Attal N, Andrade DC, Adam F, Ranoux D, Teixeira MJ, Galhardoni R, et al. Safety and efficacy of repeated injections of botulinum toxin $A$ in peripheral neuropathic pain (BOTNEP): a randomised, double-blind, placebocontrolled trial. Lancet Neurol. 2016 May;15(6):555-65. https://doi.org/10.1016/S1474-4422(16)00017-X

8. Toh HS, Maharjan J, Thapa R, Neupane KD, Shah M, Baral $S$, et al. Diagnosis and impact of neuropathic pain in leprosy patients in Nepal after completion of multidrug therapy. PLoS Negl Trop Dis. 2018 Jul;12(7):e0006610. https://doi.org/10.1371/journal.pntd.0006610

9. Santos DF, Mendonça MR, Antunes DE, Sabino EF, Pereira RC, Goulart LR, et al. Revisiting primary neural leprosy: Clinical, serological, molecular, and neurophysiological aspects. PLoS Negl Trop Dis. 2017 Nov;11(11):e0006086. https://doi.org/10.1371/journal.pntd.0006086

10. Calixto MF, Marciano LH, Prado RB, Nardi SM, Marques T. Functioning and Disability in Leprosy. Indian J Lepr. 2016 Jul-Sep;88(3):137-46.

11. Gonçalves SD, Sampaio RF, Antunes CM. Fatores preditivos de incapacidades em pacientes com hanseníase. Rev Saúde Pública. 2009 Apr;43(2):267-74 https://doi.org/10.1590/S0034-89102009000200007

12. Pimentel MIF. O exame neurológico inicial na hanseníase multibacilar: correlação entre a presença de nervos afetados com incapacidades presentes no diagnóstico e com a ocorrência de neurites francas. An Bras Dermatol. 2003 Sep-Oct;78(5):561-8. https://doi.org/10.1590/S0365-05962003000500005

13. Ramos JM, Alonso-Castañeda B, Eshetu D, Lemma D, Reyes F, Belinchón I, et al. Prevalence and characteristics of neuropathic pain in leprosy patients treated years ago. Pathog Glob Health. 2014 Jun;108(4):186-90. https://doi.org/10.1179/2047773214Y.0000000140

14. Ministério da Saúde (BR). Secretaria de Vigilância das Doenças Transmissíveis. Hanseníase. Boletim epidemiológico. Brasília, DF: Ministério da Saúde; 2018.

15. Reis FJ, Lopes D, Rodrigues J, Gosling AP, Gomes MK. Psychological distress and quality of life in leprosy patients with neuropathic pain. Lepr Rev. 2014 Sep;85(3):186-93.

16. Chen S, Qu J, Chu T. Prevalence and characteristics of neuropathic pain in: the people affected by leprosy in China. Lep prev. 2012 Jun;83(2):195-201.

17. Patil S, Willett O, Thompkins T, Hermann R, Ramanathan S, Cornett EM, et al. Botulinum toxin: pharmacology and therapeutic roles in pain states. Curr Pain Headache Rep. 2016 Mar;20(3):15. https://doi.org/10.1007/s11916-016-0545-0

18. Chen YW, Chuang SK. Botulinum Toxin A might be an alternative or adjunct therapy for the treatment of trigeminal and postherpetic neuralgia. J Evid Based Dent Pract. 2017 Sep;17(3):259-61. https://doi.org/10.1016/j.jebdp.2017.06.006 
19. ParkJ, Park HJ. Botulinum toxin for treatment of neuropathic pain. Toxins (Basel). 2017 Aug;9(9):1-14. https://doi.org/10.3390/toxins9090260

20. Xiao L, Mackey S, Hui H, Xong D, Zhang Q, Zhang D. Subcutaneous injection of botulinum toxin a is beneficial in postherpetic neuralgia. Pain Med. 2010 Dec;11(12):1827-33.

https://doi.org/10.1111/j.1526-4637.2010.01003.x21
21. Finnerup NB, Attal N, Haroutounian S, McNicol E, Baron R, Dworkin $\mathrm{RH}$, et al. Pharmacotherapy for neuropathic pain in adults: a systematic review and meta-analysis. Lancet Neurol. 2015 Feb;14(2):162-73. https://doi.org/10.1016/S1474-4422(14)70251-0

22. Dworkin RH1, O'Connor AB, Audette J, Baron R, Gourlay GK, Haanpää $\mathrm{ML}$, et al. Recommendations for the pharmacological management of neuropathic pain: an overview and literature update. Mayo Clin Proc. 2010 Mar;85(3 Suppl):S3-14. https://doi.org/10.4065/mcp.2009.0649 